\title{
PSYCHOANALYSIS AND HUMANISM: THE PERMUTATIONS OF METHOD
}

The theological response to psychoanalysis has been an on-going effort to say "yes, but..." to Freud. In 1936, writing to Ludwig Binswanger regarding the psychoanalytic view of human experience, Freud acknowledged, "I have always lived on the ground floor and in the basement of the building."' This seeming admission may be taken as the charter of many subsequent critiques of Freud, whether they be broadly humanistic or specifically theological. The consistent effort has been to affirm Freud's insights but to amplify his psychology, introducing a greater appreciation of such higher aspects as freedom, value and the human search for meaning.

Now I think it is fair to say that in rejecting a Freudian reductionism which tended toward being a materialist metaphysic, most of these critiques tended toward an alternative position which was, itself, either explicitly or implicitly metaphysical. The root metaphor of this metaphysic, as the image of a many-storied mansion suggests, was predominantly hierarchical. The psychology of Abraham Maslow is an obvious example, but the model may be extended through various stage-theories of human development to include many forms of Freudian revisionism as well. For purposes of a general typology, the various instances of this approach may be gathered under the rubric of a "humanistic" psychology. ${ }^{2}$ It is a position which has demonstrated a powerful appeal in many areas of theology, both practical and theoretical.

But already in the 1950's, Paul Tillich and Reinhold Niebuhr had voiced fundamental reservations. Tillich, for example, held that in psychologists such as Erich Fromm "we miss the depths of Freud. We miss the feeling for the irrational element that we have in Freud and in much of the existentialist literature."'3 In short, efforts at revision had

${ }^{1}$ Less often cited is the context of Freud's "admission": "Of course, I don't believe you. I have always lived on the ground floor and in the basement of the building-you maintain that on changing one's viewpoint one can also see an upper floor housing such distinguished guests as religion, art and others. You are not the only one; most cultivated specimens of homo natura think likewise. In this respect you are the conservative, I the revolutionary." The Letters of Sigmund Freud (New York: Basic Books, 1960), p. 431. See R. Jacoby, Social Amne sia: A Critique of Conformist Psychology from Adler to Laing (Boston: Beacon Press, 1975), p. 55.

The present essay is indebted to conversations with Professors Rodney Hunter and Rudolf Makkreel of Emory University, and with members of the working group on hermeneutics at the 1978 annual meeting of the Society for Values in Higher Education. A special word of thanks is due Professor Edward Casey of SUNY at Stony Brook.

${ }^{2}$ A fuller characterization of "humanistic psychology" will be found under that heading below. In the present text "the humanist" is to be understood as a shorthand term referring primarily to the humanist psychologist. Regrettably limitations of space will preclude discussion of the distinctive contribution of C. G. Jung.

${ }^{3}$ P. Tillich, Theology of Culture (New York: Oxford, 1959), p. 122; cf. R. Niebuhr, 
too often suppressed Freud's critical edge and his tragic vision. Yet the continued popularity of humanistic approaches made it evident that the neo-orthodox dissent had gone substantially unheeded. In retrospect the reason for this theological impasse is apparent: the theologians did not yet dispose of the conceptual tools which they needed in order to make their criticism stick and to forge a viable alternative. As regards making the criticism stick, there was the irony that in principle the desired aspects of Freud had been affirmed and incorporated within the hierarchical framework. It would require close conceptual scrutiny to show that in practice certain features had been smothered within the commodious embrace. And as regards an alternative, the only option at hand was an existential psychology which finally proved insufficiently comprehensive - thus the further irony that the theologians themselves were driven back upon some form of the hierarchical model. On both counts the theologians found little assistance from the side of philosophy, which, particularly in the English-speaking world, remained largely aloof from any engagement with psychoanalysis.

In 1965 Paul Ricoeur's monumental study appeared under the title De l'interprétation: Essai sur Freud. The very title suggested a response to the theological need, the introduction of a distinctively hermeneutical framework which might afford analytic discrimination and general comprehensiveness. It soon became evident that Ricoeur had indeed shifted the grounds of the debate. In his hands the competing metaphysics, materialist and hierarchical, became alternative moments of interpretation, the "archeological" and the "teleological," 4 and these moments were effectively contained within the larger setting which he characterized as "the conflict of interpretations." The significance of this shift to hermeneutics may be measured by its effects. Hierarchy was no longer assumed as normative; it was relativized to the role of one alternative among others. Moreover the relation between the two frameworks was no longer one of subsumption; it became a dialectical interaction. And accordingly Freud's "hermeneutic of suspicion" became more than a partial insight; it attained to a positive significance in its own right. The theme of a more authentic pluralism, introduced by Ricoeur's turn to hermeneutics, was to reappear in writers as diverse as Peter Homans, Don Browning and James Hillman.

Elsewhere I have been compelled to argue, however, that just as the hierarchical-metaphysical approach is appealing in principle but inadequate in practice, so Ricoeur's own hermeneutical approach falls short of its initial vision. ${ }^{5}$ In the present essay I suggest that what is needed is a further extension of the reflective "detour" which Ricoeur has opened up, a further unfolding of the mediating offices of

\footnotetext{
"Human Creativity and Self-Concem in Freud's Thought," in B. Nelson, ed., Freud and the Twentieth Century (New York: Meridian, 1957), p. 271. pp. $459 \mathrm{ff}$.

${ }^{4} \mathrm{P}$. Ricoeur, Freud and Philosophy (New Haven: Yale University Press, 1970),

${ }^{5} \mathrm{~W}$. Lowe, Mystery and the Unconscious: A Study in the Thought of Paul Ricoeur (Metuchen: Scarecrow Press, 1977); see also my review article on Ricoeur, Homans and Browning in Religious Studies Review 4, 4 (1978), 246-54.
} 
philosophy. ${ }^{6}$ But I believe that the effect of such investigation will be to relativize the role of hermeneutics itself, by restoring the psychological discussion to its philosophic rootage in the tradition which issues from Hegel and Kant. To lay the ground for this argument, a first section will introduce a simple typology, arranged in a heuristic diagram; the purpose of this schema is simply to bring to attention certain neglected issues and themes. A second, longer section will then seek to interpret these issues by placing them in the context of transcendental philosophy, and a concluding section will offer some summary observations.

Let us begin by asking: what is the shape of the psychological terrain which is available to the theologian post Freud? The question stipulates that while our concerns are finally theological, the task at hand is preparatory: namely to set forth certain underlying issues which must inform any theological assessment of the options within psychology. Further, the reference to Freud stipulates that for purposes of focus, the discussion will center upon certain positions which are related, whether positively or negatively, to Freud's pioneering account of the unconscious.

The simplest access to the issues is perhaps the straightforward typology with which we began: Freudian psychoanalysis versus humanistic psychology, with the attendant contrast between a materialist and a hierarchical world view. From this starting point one could then proceed to soften the contrast, showing for example that Freud may be reinterpreted in the direction of a more ample psychology. Thus the initial positions would become the poles of a spectrum and the task would be to fill in the options: neo-Freudians to the right, postFreudians to the left, the entire symphony. But our own aim is to sharpen the issues, and we will not accomplish this by immersing ourselves in the subtleties of an intermingling spectrum. Instead let us stick to a few ideal types, trying to tease out their inherent logic. I propose to introduce between Freudia psychoanalysis and humanistic psychology one mediating type which I shall call "existential psychology." This title suggests the thought of Martin Heidegger, but in the individual types as in the arrangement at large we must be prepared to trade subtlety for clarity. Thus our primary model of an existential psychology will rather be the early writings of Jean-Paul Sartre.

The addition of this third type has a prima facie plausibility if one recalls that Tillich and Niebuhr characteristically invoked existentialist themes in their effort to find an alternative to both Freudian psychoanalysis and humanistic psychology. And the resultant arrangement, with existential psychology inserted between the other two, makes sense in terms of common usage. Sartre speaks of an "existential psychoanalysis" and he has also declared that "existentialism is a

${ }^{6}$ Cf. P. Ricoeur, The Conflict of Interpretations: Essays in Hermeneutics (Evanston: Northwestern University Press, 1974), pp. 6-11. 
humanism" - but it would be appropriately difficult to find a joining of the two extremes, a "humanistic psychoanalysis." The remainder of the present section will test this arrangement by examining the affinities and contrasts which it suggests. As an anticipatory summary, a way of construing the conceptual terrain, I propose to amplify our three-part typology by means of the following schema:

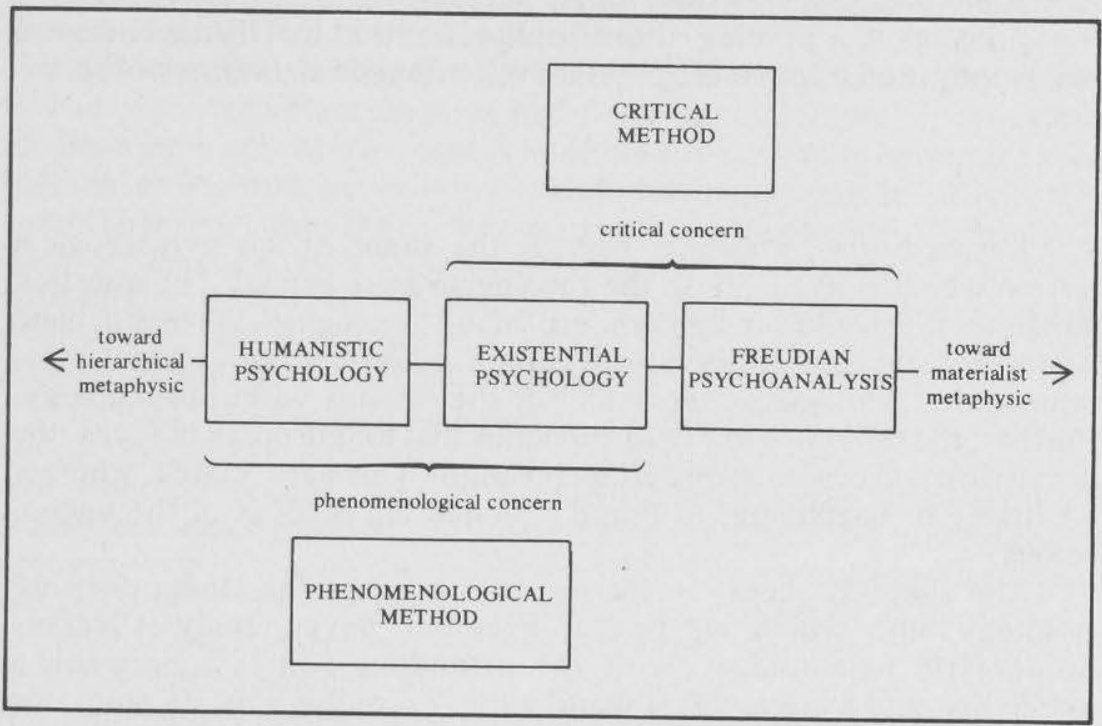

This initial schematization of the issues and themes which we shall confront may gain significance as the discussion proceeds.

A good place to begin is with the obvious affinities between humanistic psychology and existential psychology. Maslow, Allport, Rogers and May have all endorsed the quest for an existential psychology: they are variously intent upon moving with Heidegger beyond the mere "ontic" or with Kierkegaard beyond the "aesthetic" toward the fullness of human experience. ${ }^{7}$ Enumerating a few of the shared concerns which characterize this alliance, we find a series of pointed contrasts to the materialist alternative. For humanistic psychologists shared (1) a resolve to describe phenomena in their own terms, rather than explain them in other terms. Specifically (2) both groups wish to describe in terms of meaning for an existing subject, rather than explain in terms of the causality of certain forces. All of this (3) in the context of our relational being-in-the-world, rather than in the setting of some postulated system of psychic structures. Thus the bracket to the lower left of the diagram, for concerns such as these may be spoken of as distinctively "phenomenological."

These engaging affinities have inclined many not only to connect humanistic and existential psychology, but to use the terms inter-

${ }^{7}$ Cf. R. May, Existence: A New Dimension in Psychiatry and Psychology (New York: Basic Books, 1958); Existential Psychology (New York: Random House, 1960). 
changeably. But if we acknowledge Sartre as exemplar and Heidegger as progenitor, existentialism presses upon us a further range of concerns which find little place among the commitments of humanistic psychology. For classical existentialism views the human under the sign of separation and estrangement. To speak of "the human," as the humanist so readily does, is not in fact to confer an identity-it is to expose an absence. "Existence precedes essence." The truth is that our existence is secured by no human nature, it has only a destiny; and our destiny has no goal but freedom-pointless and inescapable. We are "condemned to freedom." Knowing this in our hearts, we are filled with anxiety; we flee into the comfort of some predetermined role or some self-identical human nature. The task of an existential psychology thus becomes clear: it must be a singleminded unmasking of our inveterate self-delusion. ${ }^{8}$

This is the very stuff of existentialism. Drained of this iconoclastic strain, this tragic vision, the term becomes empty and vapid. Yet these are the very themes which are most readily submerged as existentialism moves toward the side of humanistic psychology. The sense of novelty with which the writings of Ernest Becker were received in some quarters may be taken as a measure of how far this eviscerating tendency has progressed. For what Becker did was to reinterpret Freudian psychoanalysis, taking as his touchstone this sobering aspect of classical existentialism. A recognition of this face of existentialism is, in any case, the fulcral point for an understanding of our own typology. For the neglect of this aspect of existentialism cannot be dismissed as an accident of the humanistic temperament; it has rather to do with the humanist's pre-commitments, and with the commitments' logic. (1) The existentialist distrusts our self-presentation, whereas the humanist, reacting against the cynicism of Freud, inclines toward acceptance and affirmation. (2) The existentialist sees separation where the humanist, rejecting Freud's conflict theory, prefers images of reconciliation and wholeness. (3) The existentialist sees denial and flight where the humanist, in the face of Freud's pessimism, posits a spontaneous penchant toward integration and growth. Clearly we have isolated within existentialism an aspect which is distinct from the phenomenological. We might call it the tragic vision; but since we have an eye toward method, let us speak of a "critical concern."

The two faces of existentialism, phenomenological and critical, may be taken as proof of the richness of this school. But to appreciate these aspects is also to admit the tension that exists between them. For (1) a relentless interrogation of our customary way of seeing ourselves is one method, a straightforward description of what presents itself is quite another. And (2) if we are convinced that humanity is wedded to denial and self-forgetfulness, we will be reluctant to treat experience in terms of the manifest meaning as affirmed by the experiencing subject. Finally (3) an acute sense of separation and estrangement must surely

${ }^{8} \mathrm{~J}$.-P. Sartre, Being and Nothingness: An Essay on Phenomenological Ontology (New York: Philosophical Library, 1956), p. 625ff. 
tax the relational coherence of our being-in-the-world. In the face of these tensions one might even question whether there is such a thing as a unitary "existentialism." My own sense is that there can occur an interaction of concerns, a dialectical refinement, and that something of this sort has been at the core of classical existentialism. But for the present it is enough to observe that a dialectic cannot even begin to take hold until the concerns have been adequately recognized and distinguished.

A recognition of the crtitical concern has the further effect of surfacing a subterranean link between two unlikely bedfellows, the existential psychologist and the orthodox psychoanalyst. The historian Gerald Izenberg has suggested that psychoanalysis and existentialism constitute two successive and related phases of this century's crisis of autonomy. ${ }^{9}$ Erich Heller has remarked that Freudian psychoanalysis may be the most stringent attempt ever undertaken to interpret consciousness in a manner which is not tacitly hierarchical $;{ }^{10}$ and similarly Heidegger's invocation of dasein may be seen as a thoroughgoing effort to elude certain hierarchical pre-commitments which attach to the term "'human being."'11 Accordingly the affinities between existential psychology and Freudian psychoanalysis may be summarized by noting the following points of contrast to the humanistic alternative. (1) Both are bent upon unmasking our conventional self-presentation: the existentialist Nietzsche joins Freud and Marx within Ricoeur's "hermeneutic of suspicion."'12 And (2) both submit our lives to the sign of tragic separation: an analogue of the existentialist theme asserts itself among Freud interpreters as diverse as Otto Rank, Norman O. Brown ${ }^{13}$ and most recently Heinz Kohut. ${ }^{14}$ Finally (3) as to denial and flight, Freud himself has singled out the concept of repression as the touchstone of psychoanalytic theory. ${ }^{15}$ Thus the second bracket, which appears to the upper right of the diagram.

Finally, introducing the existentialist type serves to bring to light a tacit agreement between the avowed opponents, the humanistic psychologist and the Freudian psychoanalyst. Both lean toward positing some self-identical human nature, whether higher or lower, virtual or actual-and thus in the eyes of the existentialist, both tend to promote a subtle inauthenticity. Moreover, the existentialist critique of the alternatives at this point does not simply dissent on a point of description: in

\footnotetext{
${ }^{9} \mathrm{G}$. Izebberg, The Existential Critique of Freud: The Crisis of Autonomy (Princeton: University Press, 1976), p. 4.

${ }^{10}$ E. Heller, "Observations on Psychoanalysis in Modern Literature," in J. Smith, ed., Psychiatry and the Humanities, Vol. 1 (New Haven: Yale University Press, 1976).

${ }^{11}$ W. Lowe in Religious Studies Review 4, 4 (1978), 271-72.

${ }^{12}$ Ricoeur, Freud and Philosophy, pp. 32-36.

${ }^{13}$ N. Brown, Life Against Death: The Psychoanalytical Meaning of History (New York: Random House, 1959), p. 115.

${ }^{14} \mathrm{H}$. Kohut, The Restoration of the Self (New York: International Universities Press, 1977), p. 91.

${ }^{15}$ S. Freud, "An Autobiographical Study," in J. Strchey, ed., The Standard Edition of the Complete Psychological Works of Sigmund Freud, Vol. 20 (London: Hogarth, 1959), p. 30.
} 
terms such as "bad faith" the moral passion is unmistakable. Yet for all its determination to set itself apart in substance and in tone, existentialism remains susceptible of certain alliances. It will adopt the rhetoric of humanism to convey a phenomenological disdain for the reductionism of the psychoanalyst, and it will acknowledge the Freudian unconscious as a canny though misguided premonition of the human penchant for self-forgetfulness. In sum, there is reason to recognize existentialism as a discrete alternative and yet to place it on a common footing alongside the other options.

This completes our lateral movement across the initial diagram. Before we proceed to the next section, however, we need one further refinement. To speak of a phenomenological concern must call to mind the philosophy of Edmund Husserl, "the father of phenomenology." This association is appropriate enough, for between Husserl and humanistic and existential psychology flow lines of strong historical influence. What is less commonly discussed, however, is the substantial discontinuity which obtains as well. Husserl's response to "the crisis of European man" was a spirited advocacy of a more rigorous philosophy. For the crisis sprang from a failure of nerve: our capacity for reflection, which is the ground of humanism, had never really entered into its own. It remained confused and self-forgetful, enmeshed in "the natural attitude," a naive immersion in the world; and for this irresolution the humanist must share the blame. ${ }^{16}$ The diagnosis may sound existentialist, but the prescription which followed from it does not. For in Husserl's eyes a few phenomenological concerns and a prophetic posture do not a phenomenologist make: Husserl's solution looked not to engagement but to an intensified reflection. By a stringent discipline of thought, self and world would eventually be seen to converge in the immanent self-transparency of "the transcendental ego." 17

Even among those who presumed to understand this Husserlian vision, the majority chose to reject the project as the defiant boast of a moribund metaphysic. But skeptic and convert alike were agreed at least on this-that Husserl had succeeded in setting forth an acutely distinctive method. This is the awkward fact which gets obscured by the common, diffuse usage of the term "phenomenology." To keep Husserl's challenge before our minds, I wish therefore to distinguish from a broadly phenomenological "concern," the more rigorous phenomenological "method." 18 But as soon as we take that step, the itch for tidiness compels us to ask whether there should not be a further, complementary term, a "critical" method as well. I propose to argue that such is indeed the case, and for reasons which transcend the diagrammatic. Recent philosophy has evinced a mounting interest in the

\footnotetext{
${ }^{16} \mathrm{E}$. Husserl, Phenomenology and the Crisis of Philosophy (New York: Harper and Row, 1965).

${ }^{17}$ Husserl, Ideas: General Introduction to Pure Phenomenology (London: Allen and Unwin, 1931), pp. 232-34; R. Sokolowski, The Formation of Husserl's Concept of Constitution (The Hague: Martinus Nijhoff, 1964), pp. 136-39.

${ }^{18} \mathrm{Cf}$. H. Spiegelberg, The Phenomenological Movement, Vol. 1 (The Hague: Martinus Nijoff, 1960), pp. 3ff.
} 
Frankfurt School of Critical Theory, and within that movement the purest case is perhaps that of Theodor Adorno. Here as with Husserl we catch the visionary voice with its characteristic marks of intransigence and idiosyncracy; and with critical theory as with phenomenology, the reviews varied accordingly. We will have occasion to arrive at our own assessment in the course of the following section. For the present it is enough to add this last element to our schema, recognizing that it stands more as a question than as a datum.

Recognizing the overarching concerns, phenomenological and critical, helps us appreciate the psychological schools as something other than watertight compartments. The way in which the concerns overlap the schools shows how the positions may interpenetrate; it suggests that there is a logic to the way in which the schools have actually interacted. At the same time, however, the distinction which we have drawn between concern and method serves as a reminder that we are not simply dealing with an undisturbed spectrum. There are issues at stake, choices to be made, and it is to a clarification of these issues that the present section now turns. I propose to consider the entire schema-the two methods as well as the three "schools" - as an expanded five-part typology. We will examine these several options seriatim, seeking to understand the underlying logic by which they rise and fall.

\section{Humanistic Psychology}

"Humanism" in psychology has become the rallying point for an amazing array of actual practices. Yet there is throughout the clan a certain family resemblance, among the salient features of which are an insistence upon holistic thinking and a championing of certain values. ${ }^{19}$ Now much of the drama of humanistic psychology, and of psychology at large, is generated at just this point-by the dialectic of value and whole. To appreciate this dialectic we must first distinguish an initial, rather rhetorical level at which the two themes simply coalesce. The humanist frequently charges that both Freudianism and behaviorism have considered the person solely in terms of those lower aspects which are shared with the animal and material realms. What is needed is a more holistic psychology which has room for the higher aspects as well-namely those capacities or values which make us distinctively human. We are thus returned to the many-storied mansion. But beyond this initial point of hierarchical concord there lies a fundamental tension, which traces back to the psychology's ambivalence toward its very namesake, the humanism of the Enlightenment. For on the one hand, humanistic psychology stands in clear continuity with the Enlightenment; and in so doing it inherits a characteristically modern crisis in the relationship

\footnotetext{
${ }^{19} \mathrm{~A}$. Sutich and M. Vich, Readings in Humanistic Psychology (New York: The Free Press, 1969), pp. 6-9; O. Strunk, "Humanistic Religious Psychology: A New Chapter in the History of Religion," in H. N. Malony, ed., Current Perspectives in the Psychology of Religion (Grand Rapids: Eerdmans), p. 31.
} 
between notions of value and notions of the whole. On the other hand, humanistic psychology seeks to transcend the Enlightenment tradition; and in so doing it reaches toward a resolution, a renewed cooperation of value and whole.

To begin with the first aspect, we may recall that for the Enlightenment "the distinctively human" was a potent value term. In spelling out the concept, the Enlightenment tended to equate the distinctively human with the exercise of freedom. And then by an elision of thought it defined freedom as the ability to distinguish oneself-the ability to stand over against nature, against society, against the heteronomous "whole." This thrust toward individual liberation continues to exercise great appeal within humanistic psychology; it accounts for that side humanistic psychology which opens in the direction of existentialism.

The second aspect of humanistic psychology stems rather from a rebellion against the Enlightenment, specifically a rebellion against a further definition of the distinctively human. For the Enlightenment also defined the distinctively human as the exercise of reason; and here once again the Enlightenment drifted from distinction to separation, tacitly honoring the notion of a disembodied mind. At this point the humanistic psychologist's rejection of the Enlightenment heritage is totally unambiguous: to be fully human is to be in touch with our bodies, our affects are part of our very humanity. Nor is this a minor shift, as if one were simply adding another element to the picture. For the significance of affect is precisely that it puts us in touch with our larger context-in touch with the larger whole. Thus humanistic psychology has at least partially recognized that the problem with the tradition lies not so much in this or that definition, but in the persistent tendency in all its definitions to see distinctiveness as over-againstness, as if the specific were secured by isolation. It follows that when, in contrast, the humanistic psychologist makes central to our humanity the capacity for openness, encounter or love, the intent is more than sentimental; it is an effort to appreciate the distinctive precisely in that which is most relational. Thus this side of humanistic psychology asserts what the individualism of the Enlightenment would deny: that the distinctive is the best affirmed by its being grounded, within a larger whole. Accordingly this is the "transpersonal" side of humanistic psychology, which faces in the direction of a comprehensive metaphysic. ${ }^{20}$

The search for a larger context, like the interest in Eastern religions which often accompanies it, may be profound or superficial. A good litmus in this regard is the degree to which the humanist recognizes that in contemporary culture an appeal to values raises as many questions as it resolves. It is not enough to affirm the human quest for meaning; one must face the unnerving question of whether meaning is found within the world or simply projected upon it. Similarly one must ask of values, are

${ }^{20}$ Strunk, "Humanistic Religious Psychology," p. 34; R. Ornstein, ed., The Nature of Human Consciousness: A Book of Readings (San Francisco: W. H. Freeman, 1968). for an illuminating semi-popular discussion of issues raised by transpersonal psychology, see P. Slater's Earthwalk (Garden City: Doubleday, 1974) and his The Wayward Gate: Science and the Supernatural (Boston: Beacon Press, 1977). 
they subjective or objective, human craft or a gift of the cosmos? In effect it is a matter of recognizing the crisis of which we spoke earlier, the crisis in the relationship of value and whole. Paul Ricoeur has acknowledged that "... philosophy at the present time is entirely at an impasse concerning the problem of the origin of values. We are condemned to vacillate between an impossible creation of values and an impossible intuition of values. This theoretical failure is reflected in the practical antinomy between submission and rebellion that infects the daily concerns of education, politics and ethics." ${ }^{21}$ It would be unfair to stick the psychologist with these questions, for they are not of the psychologist's making. But the psychologist must be asked to join others in confronting the common quandary. For in certain cases one senses in the advocate of values that heady and unreflective buoyancy which is the mark of the recent convert.

In the more interesting cases, however, it is clear that a response to the crisis has been embodied in the very notion of a humanistic psychology. The very term represents an effort to fuse the inwardness of the humanistic tradition with the objectivity of empirical science; in this fashion humanistic psychology essays the inescapable task of thinking at one and the same time in terms of the distinctive and in terms of the whole. This boundary stance joining science and humanism commends itself for reasons both symbolic and practical. Symbolically, to live on the boundary, at the point of greatest tension, is a way of bearing witness to a more fundamental ground which transcends our notions of subjectivity and objectivity. And practically the boundary stance represents a straightforward decision to get on with answering the needs at handextending to science the virtues of the heart, bringing the sentiment to the rigor of the mind and offering to all who seek it the powers of a healing empathy.

\section{Phenomenological Method}

From another angle however a mixed method is not method, but confusion; and a boundary stance will just reinforce the cacophony of the present crisis. For the phenomenologist the source of the confusion is the failure to see that the distinctively human is precisely not what the humanist makes of it, a part within a larger whole. Rather our distinctiveness is to be found in our capacity to have a whole-which is to say, in our capacity to "intend" a world. Indeed one might almost say that the revolution of phenomenology is to have placed the seeming whole, the world, within the distinctively human. It is here that the paths divide. For the humanistic psychologist can acknowledge the point and yet see the issue as a relative question. Between subjective and objective, "inner" and "outer," which is the part and which the whole? Why neither and both: the mistake is in thinking one has to choose. The human paradox is the deeper truth, that both perspectives are true. For the phenomenologist, in contrast, the choice cannot possibly be resolved into complementary viewpoints. The issue is rather a demand for a

\footnotetext{
${ }^{21}$ Ricoeur, The Conflict of Interpretations, p. 449.
} 
radical conversion of the mind, another level of reflection. To Husserl the naturalism of the scientistic world view was idolatry, and his response was properly prophetic. For to bargain with idols is impossible; it is to place oneself in a position which is already fatally compromised. ${ }^{22}$

The results of the Husserlian rigor may be illustrated with regard to "being-in-the-world," the leitmotif of the "phenomenological concern." Humanist and phenomenologist are at one in affirming the phrase, but to the humanist "being-in-the-world" means that we participate in the world-whereas for the phenomenologist it means that we participate in the process of intending a world. It is in this way that phenomenology opens up a second level of reflection. It steps back to ask the antecedent question, "why is there something rather than nothing at all?" It shakes the dogmatic slumbers of the "natural attitude," which naively assumes the givenness of the world and then fancies itself scientific because it proceeds to inquire within it. Moreover the question is not simply a matter of propadeutic, which could be addressed and then set aside. For the phenomenologist responds to the question by laying bare the process of intending; and that process, once understood, radically alters our apprehension of every experience. Each thing, each experience without exception, will be seen as a "presentation": that is, as the noematic or, very roughly, the "objective" face of a corresponding noetic, "subjective" act. ${ }^{23}$

It is in this fashion that phenomenology proposes to be critical. It is bent upon following through the Copernican revolution of viewpoint initiated by Immanuel Kant-namely the recognition of the allpervasive and generative activity of the knowing subject. The extent of the revolution may be gauged by the impact it has upon our common, pre-critical notions of wholeness and value. The world which once seemed the whole is subjectivized, becoming a function of intentional activity. And values are not simply invoked and presupposed; their very constitution becomes the topic of methodical scrutiny. Yet the critical shift is not simply negative: Kant's aim was to "justify" such conceptions as space, time, freedom and God, which had been merely speculative. Similarly the aim of Husserl's noetic-noematic setting is to stabilize the conceptual staggering to which Ricoeur refers in his comment on values. Indeed it can be said that we understand Husserl in the measure that we come to appreciate the critical and the foundational aspects of phenomenology not as mutually exclusive, nor even as complementary moments but as internally related: the two faces of a single quest. ${ }^{24}$

Further testimony to the positive character of phenomenology critical commitment is the fact that in the very process whereby the contents of our everyday world and everyday values are subjected to scrutiny, the essential human activities of valuing and gestalting reassert themselves in another guise. The comprehensive noetic-noematic field be-

${ }^{22}$ Husserl, Phenomenology and the Crisis of Philosophy.

${ }^{23}$ Husserl, Ideas, pp. $255 \mathrm{ff}$.

${ }^{24} \mathrm{P}$. Thévenaz, What is Phenomenology? and Other Essays (Chicago: Quadrangle Books, 1962), pp. $93 \mathrm{ff}$. 
comes the new whole; indeed it arranges itself in strata which point in the direction of hierarchy. And while the mission of the phenomenologist is not to direct but to describe, that firm descriptive intent has the effect of exalting lucidity to the level of a presiding norm. Now these affirmations become the target, in turn, for the existentialist's critique of phenomenology. There is between phenomenologist and existentialist a kinship which was implied by our diagram and which is confirmed by the recent critique of the everyday in terms of certain founding acts; for in existentialist terms such acts are the root of our fundamental responsibility. But the existentialist senses in phenomenology a certain lofty selfpossession, a feigned transcendence of the human condition of limitation and morality. In the eyes of the existentialist, phenomenology betrays its own intent of being straightforwardly descriptive-for in Husserl's realm of meaning there is no place for life's elemental absurdi-

Thus once again the conceptual path divides and again each way is honorable. To the phenomenologist, negative meaning is meaning still-else we could not talk about it. The phenomenologist may well respond to the existentialist that the community of discourse has suffered long enough from the voices of haste and alarm. In time of crisis the true existential courage, perhaps, is not to spread despair but to stand by the task, the nurturance of meaning, which Being has bequeathed us.

\section{Existential Psychology}

But for the existentialist the notion of a transcendental ego, however chastened, can only encourage us in our hankering for the chimeri$\mathrm{cal}$ vision of a superhuman self-identity. Much as the phenomenologist criticized the humanist for failing to follow through on Kant's Copernican revolution, so the existentialist chides the phenomenologist. For phenomenology affirms the Kantian insight that the experiencing subject is pervasively active-and yet the phenomenologist carries over from the earlier empiricism the perceptualist model of truth as correspondence or "fulfillment"; and contra Kant this locates truth not in act, but in a static identity. ${ }^{26}$ In this light the key existentialist concepts are aimed at guaranteeing what the phenomenologist let slip, the centrality of human activity; and this means that despite appearances, the concepts are not simply negative. This is true of even so extreme a case as the existentialist's preoccuption with death. Had we an eternity in which to act, our time would have little meaning. Because we do not, time

${ }^{25}$ Sartre, Being and Nothingness, pp. 438-39.

${ }^{26}$ This criticism represents a disputed point in the interpretation of phenomenology; useful in this regard is the study by Alphonse de Waelhens, Phénomenologie et vérité: Essai sur l'évolution de l'idée de vérité chez Husserl et Heidegger (Paris: Presses Universitaires, 1953). The critique of identity theory has been formative for the thought of the Frankfurt School. See T. Adorno, Negative Dialectics (New York: Seabury Press, 1973), pp. 22-24 and passim; J. Habermas, Knowledge and Human Interests (Boston: Beacon Press, 1971), pp. 5, 301ff; M. Jay, The Dialectical Imagination: A History of the Frankfurt School and the Institute of Social Research, 1923-1950 (Boston: Little, Brown and Co., 1973), pp. 46-47. 
matters. But this is to say that our lives can have meaning not simply in spite of, but because of, the constant fact of mortality.

The charge against phenomenology, in brief, is that it is insufficiently critical. Phenomenology affirms Kant's effort to gain critical distance, to fight free of the immediacies of the natural attitude, and yet at the same time it unreflectively perpetuates an ideal of truth as presence: intuitive and immediate..$^{27}$ Now if this is indeed the import of the existentialist's dissent, it follows that the further step which existentialism proposes is a step within the transcendental context. This point must be stressed in the face of the popular identification of existentialism with humanistic psychology, as if the existentialist dissent represented a common-sense dismissal of Husserlian " idealism, " a simple rejection of transcendental thought. This misapprehension is partly the work of the existentialist's own rhetoric; like the language of drama which it resembles, it seems to disdain reflection in favor of intuitive recognition. But I wish to suggest that, apart from the progression of argument which we have been tracing, existentialism loses its conceptual girding, resolves to pure emotion and drifts toward empty self-parody.

A case in point is the central issue of one's relationship to oneself. For the existentialist this self-self relationship comes close to being the determinative whole; certainly in any case a shouldering of the relationship is the existentialist's determinative value. Kierkegaard set the stage with the first page of The Sickness Unto Death by contending that "the self is a relation which relates itself to its own self...." But in the pragmatic atmosphere of humanistic psychology, this vision becomes oddly distended. To ask how one feels about one's self-image is not yet to engage a more radical self-self relationship. And to advocate holism is to miss the insight that the self is not simply a whole, but a whole-whole relationship. This paradoxical relationship is a distinctively modern notion, one which Kant made possible and Hegel made essential. ${ }^{28}$ When Sartre berates the experimentalist and the psychoanalyst for trying to construct out of parts the whole-whole relationship which they already, uncritically, must presuppose, his criticism is simply an adaptation of the peculiar holism of Kant's transcendental epistemology. When Sartre holds that the failure is moral, a ruse of bad faith, he is recalling the "unhappy consciousness" as Hegel once evoked it. ${ }^{29}$ Sartre, for his part, was mindful of this rootage. Subsequent events seem to confirm that, severed from this context, existentialism drifts toward the onedimensional.

Accordingly the critics of existentialism, to turn to them, must be distinguished as to whether or not they engage the issue within the

${ }^{27}$ M. Heidegger, Being and Time (New York: Harper and Brothers, 1962), p. 47; R. Sokolowski, The Formation of Husserl's Concept of Constitution, pp. 200-01.

${ }^{28} \mathrm{Cf}$. L. Trilling, Sincerity and Authenticity (Cambridge: Harvard University Press, 1971), pp. 26ff.

${ }^{29}$ R. Bernstein, Praxis and Action: Contemporary Philosophies of Human Activity (Philadelphia: University of Philadelphia Press, 1971), pp. 84ff. 
transcendental context. It is commonly acknowledged for example that existentialism has little room for the insights of sociology. But stated so abruptly, the remark suggests a farrago of the two approaches, transcendental and empirical-without a commensurate awareness of the conceptual anomalies which such a mixed method may entail. The more promising tack is once again to draw upon warrants which are common to transcendental discourse, to suggest respects in which existentialism too is insufficiently critical. Husserl's uncovering of intentional activity was critical in a sense derived broadly from Kant: it displayed the conditions of the possibility of the natural attitude. The existentialist's treatment of Husserl, in turn, with regard to immediacy and mediation, shows remarkable resemblance to Hegel's critique of Kant. ${ }^{30}$ An imminent scrutiny of existentialism will present itself as a further extension of this classic debate.

As background to the critique of existentialism, we may recall that existentialism concurs with phenomenology on the centrality of the self-self relationship. The existentialist turn upon phenomenology is simply to add that, de facto, the relationship is never fully realized, it can never resolve to a condition of self-identity. Rather we find that we are sundered within by our "thrownness" and temporality; and it is only in recognizing this comfortless reality that we attain to a condition of authenticity. At just this point, however, the critic of existentialism may charge that the existentialist has in fact capitulated to a subtle variant of the old dream of self-identity. For in acknowledging that my condition is one of relentless separation, I enter upon an undeluded correspondence with my condition, which is the very meaning of authenticity. And can this be anything other than the correspondence theory of truth, once rejected and now reborn as a self-identity of the will? The question is an adaptation of Hegel's critique of romantic consciousness; and the aim is Hegel's aim, to preserve it in performance, and not just in word, the Kantian insight into the subject's all-pervasive activity. It is well and good for the existentialist to have dramatized the crisis precipitated by historicity and temporality. But when it comes to the existentialist's response to that crisis, one must ask whether the subject's act can remain actual once it has been so compacted within a timeless "moment" of decision?

The immanent critique of existentialism is represented by the Frankfurt School of Critical Theory; again the ways divide and there is honorable disagreement. The point at issue approaches being a theological dispute over the locus of original sin. For the existentialist, all creativity traces back to the individual: to say that a group "acts" is to

\footnotetext{
${ }^{30}$ In concentrating upon the theme of mediation, I am reading the whole of Hegel in the light of one aspect of his thought, the aspect stressed particularly by Herbert Marcuse in Reason and Revolution: Hegel and the Rise of Social Theory (New York: Oxford, 1941). Equally important to any comprehensive assessment of Hegel is the more familiar aspect which is allied with " the philosophy of identity." Habermas examines the interplay of both aspects in his opening chapter, "Hegel's Critique of Kant: Radicalization or Abolition of the Theory of Knowledge." A similar interplay provides the dynamic of much of the present essay.
} 
speak in a way which is extended at best, and finally misleading. For our root temptation is the anonymous herd, a forgetfulness of the individual among the pretentions of the collectivity. And our tragic grandeur is our ability to refuse a mute immortality which is not more, but less, than human.

\section{Critical Theory}

While existentialism sides with Kierkegaard on the character of original sin, the critical theorist favors Marx. The great temptation is that of the bourgeois individualist, to cover over the harsh realities of our concrete social condition. But it must be stressed that critical theory is not a mixed method in the vein of conventional "dialectical materials," the forced marriage of an idealist logic and the data of economics. Rather critical theory emerges out of the transcendental sphere, by arguments generated within that sphere; and the issues at stake are those with which we have already become familiar.

This placing of critical theory is confirmed by a number of recent commentators. Susan Buck-Morss selects phenomenology and existentialism as key points of reference; and once again the cardinal issue is mediation: "where Adorno felt existentialism (as well as phenomenology and Lebensphilosophie) made its mistake was in accepting 'natural' phenomena as 'given' immediately in experience. Hegel had already demonstrated the illusory nature of such attempts at 'concreteness' in the opening pages of The Phenomenology of Mind...."31 Moreover, just as Husserl saw in "the natural attitude" a certain idolatry and just as the existentialist saw in the transcendental ego a supra-human presumption, so the critical theorist too has a moral stake in the debate. For regarded in the false isolation of immediacy, the object becomes an "enchantment," a "fetish" and a "fate."32 In effect, the error of previous thinkers lay in short-circuiting the critical arc: "by stopping with the immediately given object, they did not see past this fetish-like appearance, whose reified form Lukacs had analyzed as 'second nature." ',33

This concept of "second nature," which derives from Hegel, is altogether crucial. An example would be certain class differences: they are forms of domination which have wrapped themselves in a cloak of inevitability, as if they were somehow rooted in nature. Yet they are not nature but the congealed, sedimented results of past historical acts, they are "second nature." To expose the oppression which hides behind such mystification is the chief task of the critical theorist. Thus critical theory does not propose a mixed method which would seek to supplement the individualism of existentialism with certain empirical observations drawn from another field such as sociology. Indeed there is an important sense in which critical theory seeks not to offset, but to radicalize the existentialist's own distinctive insight. For like the existentialist, the critical theorist is bent upon uncovering our human free-

${ }^{31} \mathrm{~S}$. Buck-Morss, The Origin of Negative Dialectics: Theodore $W$. Adorno, Walter Benjamin and the Frankfurt Institute (New York: Free Press, 1977), p. 73.

32 Ibid., p. 55.

${ }^{33} \mathrm{Ibid}$., p. 73. 
dom and responsibility; and in the one case as in the other, the exposure is profoundly unsettling. The difference is simply that more often than the existentialist, the critical theorist finds the evidences of that alienated freedom by an analytical penetration into the givens of the social order, rather than by standing over against them.

A companion piece to the issue of mediation throughout our investigations has been the question of truth, and specifically the critique of the correspondence theory of truth with its telos of identity. Here too critical theory may be seen as continuing the earlier argument; thus Max Horkheimer, who along with Adorno originated the early critical theory, took it as his task to describe "the death of the identity principle upon which bourgeois metaphysics had been founded...." ${ }_{34}$ But the target was not simply classical metaphysics; the critical theorists so formulated the attack upon identity as to include a criticism of the concept of intentionality, which was so central to phenomenology. Moreover, Adorno, for his part, was not content to reject intentionality. He undertook the further step of expounding an alternative doctrine of "unintentional truth," a doctrine of truth as non-identity. This remarkable proposal may be understood as an insistence that historical circumstances arise inadvertently, behind our backs, and even ironically, contrary to our intentions. But the decisive thing about the notion of unintnetional truth was that it eventuated in the endorsement of a form of materialism-in critical theory the rejection of intentionality "converged with materialism in its claim that the object was the source of truth."' 35

Thus we have succeeded in locating critical theory where the diagram suggested it might be, at the confluence of the transcendental, phenomenological tradition and a certain form of materialism. But everything depends on how these terms and their relationship are understood. Buck-Morss suggests that the theorists' new direction "was 'matieralist' not so much in the Marxian sense as in the simpler sense of pre-Kantian empiricism." 36 This gloss is useful as a reminder that the theorists' appropriation of Marx was not doctrinaire and as a measure of the theorists' determination to gain a point of leverage outside of the transcendental sphere. But Buck-Morss's reading runs counter to her own recognition that the theorists criticized Husserl and others for their characteristically pre-Kantian practice of selecting for reflection objects drawn from the natural order, such as trees, rather than objects which more clearly bore the social imprint ${ }^{37}$ This criticism on the part of the critical theorists is evidence that we may say of them, as we said of the existentialists, that even in adopting those postures which appear most antithetical to transcendental discourse, they were prompted by concerns derived from that very tradition.

The prime concern is of course the Hegelian issue of mediaton. But the transcendental rootage goes deeper than this formal concern: the

\footnotetext{
${ }^{34} \mathrm{Ibid}$., p. 70.

${ }^{35}$ Ibid., p. 78 .

${ }^{36} \mathrm{Ibid}$.

${ }^{37}$ Ibid., p. 37.
} 
theorists press Hegel's issue for precisely Hegel's reasons-namely defending and extending the Kantian insight into the subject's pervasive, generative activity. For as we saw in examining the concept of second nature, a determination to penetrate to our underlying activity and responsibility is at the heart of the critical enterprise. In its refusal of transcendental pretensions for transcendental reasons, by way of a non-transcendental perspective-inserting materialism into the reflective arc in order to avert a premature cloture-critical theory represents a sort of eschatological postponement of all transcendental completion. Thus the critical theorists arrive at a profoundly dialectical stance toward the transcendental tradition. On the strength of this dialectical stance we may conclude that critical theory does embody an integral method, quite distinct from the broader matter of "critical concern."

Turning finally to evaluation, we may recall one further theme of our inquiry, namely the uneasy relationship which we have observed between notions of value and notions of the whole. Critical theory is an unmasking of the false values generated by ideology, which is the self-inflation of special interests to the level of an oppressive metaphysic, a spurious whole. This is the sense of Adorno's muchquoted maxim, "the whole is the false." 38 At the same time the critical theorists drew heavily upon a tacit recognition of a more authentic, more concrete whole; they agreed with Lukacs that "the objects of the empirical world are to be understood as objects of a totality, i.e. as the aspects of a total situation caught up in the process of historical change." ${ }^{39}$ Yet this latter whole could never be brought to articulation. Despite its concreteness, or rather precisely because it was so radically concrete, this social totality assumed the elusive but determinative station of a regulative idea. A similar situation obtained as regards the theorists' implicit anthropology and their implicit values; Martin Jay has observed, "Dialectics was superb at attacking other systems' pretensions to truth, but when it came to articulating the grounds of its own assumptions and values, it fared less well. Like its implicit reliance on a negative anthropology, Critical theory had a basically insubstantial concept of reason and truth, rooted in social conditions and yet outside of them, connected with praxis yet keeping its distance from it." 40

Critical theory is not a rounded theory so much as it is a tactic-a sort of interim ethic, a way of waiting without idols in a time of eschatological postponement. But there is no concealing the fact that this strategic incompleteness, however appropriate, does foster certain ironic dependencies. ${ }^{41} \mathrm{We}$ find ourselves returned by the requirements of the critics themselves to the humanists' original insistence upon some judicious articulation of the distinctively human, of the attendant values and of the embracing whole.

${ }^{38}$ W. Adomo, Minima Moralia: Reflections from Damaged Life (London: New Life Books, 19743), p. 50.

${ }^{39} \mathrm{G}$. Lukács, History and Class Consciousness (Cambridge, MIT Press, 1968), p. 162; cf. M. Jay, "The Concept of Totality in Lukács and Adorno,"' Telos 30, 117-37.

${ }^{40}$ Jay, The Dialectical Imagination, p. 63.

${ }^{41}$ Buck-Morss, The Origins of Negative Dialectics, p. 190. 


\section{Freudian Psychoanalysis}

Whatever their differences, phenomenology, existentialism and critical theory agree on certain premises drawn from Kant's critique of the natural attitude. When juxtaposed to this transcendental accord, the headstrong materialism of Freudian psychoanalysis must seem a misplaced item, a discordant note. But the present essay has contended that, nevertheless, the transcendental background may be the missing link we have needed in order to clarify certain issues in psychoanalysis and in its relationship to humanistic psychology. To make this case now. I must do more than simply show that between psychoanalysis and the transcendental discussion there exist certain external similarities. I will have to demonstrate that the similarities may be used to illumine psychoanalysis in its own right.

The grounds for my argument have been prepared by Paul Ricoeur in his painstaking study of Freud. Ricoeur has shown that Freud's thought is never simply that of a positivist; it is simultaneously a hermeneutic, an act of cultural interpretation. Freud speaks not only a "force language" of drives and impulses, but also a "meaning language" of dreams and wishes, of purposes and texts. ${ }^{42}$ Philip Rieff mounts a similar argument in a book which is aptly titled Freud: The Mind of the Moralist. Rieff holds that contrary to the common image of him, Freud actually rejected the materialist position according to which "mind is the agent of the body"; in its place he introduced the pregnant insight that "the body exists as a symptom of mental demands." crucial turn away from naturalism is central to Rieff's conception of Freud as moralist, as it is to Ricoeur's conception of psychoanalysis as hermeneutic. We need only add that the turn is equally central to Freud's affinity with the Kantian revolution. In both cases our conventional paradigms are shaken by the discovery of an underlying decision, an originary act.

Now it is at just this point that the analyses of Freud by theologians and humanists commonly stop short-as if the Kantian turn were itself an answer, and not a whole new set of questions as well. It is often shown that Freud is not simply a materialist, that he presupposes a certain freedom, a certain transcendence. And it is often shown that he has affinities with the transcendental turn, particularly by way of a convergence between psychoanalysis and existentialism. In this manner affirmations of three distinct sorts intermingle as if they were identical, or as if they were mutually reinforcing. To stick with the example of freedom: freedom is affirmed as a certain transcendence, as a crucial value and as a consequences of the transcendental turn toward the subject. Conflations of this sort are the substructure of many discussions of psychoanalysis and humanistic psychology-regardless of whether the discussion then concludes by locating the conflation solely on the

${ }^{42}$ Ricoeur, Freud and Philosophy, pp. 65-67.

${ }^{43}$ P. Rieff, Freud: The Mind of the Moralist (Garden City: Doubleday, 1959), p. 6; D. Browning, Generative Man: Psychoanalytic Perspectives (Philadelphia: Westminster Press, 1973), pp. $42 \mathrm{ff}$. 
side of humanistic psychology, thus favoring that position, or by placing the conflation between the two positions as a ground for common agreement.

But the burden of our entire argument has been that the very attractiveness of this bundle of affirmations serves to disguise certain fundamental dilemmas, and that the seriousness of these dilemmas is dramatized by the restless interchange, the mutual critique and complementarity, which we observe among several schools of modern thought. Thus it is no solution to conflate transcendence with the transcendental: the Kantian turn is nothing if not a sustained critique of the metaphysical transcendence which is one component of humanistic psychology. And similarly the dialectic of value and whole which we have traced throughout the transcendental sphere bears witness that the impact of Kant upon the affirmation of values is as unsettling as it is suggestive.

Such are the lessons of our discussion thus far. Now the task is to show how the same issues reassert themselves when we take up psychoanalysis in its own right. Let us consider the way in which a simple shift of emphasis in our reading of psychoanalysis may precipitate certain sharp and unattended changes. On the one hand you can stress the fact that there is an underlying human act. Reality takes on a more human face; the awareness of mental sources will give you a psychoanalysis analogous to phenomenology, with an opening toward humanistic psychology. There will be a cordial relationship of mutual reinforcement between your sense of value and your sense of the whole; and correspondingly, a supportive accord between individual and society. Rieff is speaking in this vein when he says that Freud "restored an ethical, and therefore a social, conception of human sickness," 44 and many have held that this aspect of matters is the final truth about psychoanalysis.

On the other hand you may stress that while there is such an act, it remains elusive and self-forgetful. It was this shift which caused the Kantian turn to reveal its other aspect, that of a radical decentering of the self; and similarly psychoanalysis, on the premise that our innermost acts escape immediate introspection, will press upon us a variety of techniques by which the elusive activity may be unearthed and secured. The techniques will be those of a psychoanalysis which is bent upon the dissolution of those heteronomous values and those peremptory wholes which inhibit the free exercise of autonomy. Therapy will still be moral in the sense of having a human telos, but the telos is now reduced to a negative freedom, a "freedom from"; and a freedom of this sort corrodes the loyalties which knit together the society and the individual. This is the unsettling logic which led Rieff from Freud the moralist to The Triumph of the Therapeutic. For our part we need only note that Rieff's "therapeutic personality" is the direct descendant of the existentialist. There is just one difference, which tellingly reflects that which is specific to this aspect of psychoanalysis. For the therapeutic personal-

${ }^{44}$ Rieff, Freud, p. 12. 
ity, in contrast to the existentialist, even the ultimate questions have been subjected to the implacable analysis. Ultimate concern has come to seem a hang-up.

Just as Reiff's initial turn toward seeing Freud as moralist parallels the Kantian turn toward an awareness of the subject's all-pervasive activity, so the subsequent shift of emphasis in the direction of analytic suspicion parallels the Hegelian move toward critical mediation. Now I have argued that central to Hegel's project is a determination to secure the Kantian insight; and indeed all of Hegel's philosophy may be read as a long but deliberate detour designed to accomplish this end. In like fashion we may say that one would never go to the trouble of refining the mediating techniques of analytic suspicion if one were not persuaded that there is an underlying act to be got at. Nor is it only with regard to its aims and presuppositions that psychoanalysis affirms the subject's activity: Jurgen Habermas has shown on similarly Hegelian grounds that the very method by which analysis aims to increase the subject's autonomy is, itself, a self-correcting intersubjective activity. ${ }^{45}$ This I take to be at least part of the significance of speaking of analysis as "praxis."

But psychoanalysis is praxis of a most peculiar sort; and it is at this point, in treating the distinctiveness of psychoanalysis, that Habermas proves least helpful. I propose therefore to turn instead to an interpretation of Ricoeur's exposition of Freud's distinctive "language of force." 46 The entirety of Freud \& Philosophy grows from the premise that Freud's mixed discourse of force language and meaning language is not an idiosyncracy or a muddle, but the very "raison d'être of psychoanalysis." I believe that a central argument for this irreducibility of the mixed discourse is in fact the manner in which that discourse reflects a crucial peculiarity of the analytic praxis. For while the analy tic session is indeed an interpersonal encounter, what is distinctive about it is that in this case the interpersonal relationship itself is treated as a technique. One might almost say that the innovation of psychoanalysis is to have made of the I-Thou encounter the object, and even the means, of a certain manipulation! This is the difficult reality which is transcribed in Freud's language of force. Ricoeur says that this objectifying language protrays the person insofar as she or he "has been and remains a Thing"; perhaps we may sharpen Ricoeur's point by saying that the language portrays persons insofar as their intersubjective relationships may be properly treated as things. For the analytic session focusses upon "resistance, transference, repetition"; this vocabulary and this sequence are at the core of the therapeutic situation.

Thus we find that Freud's mixed discourse points to a position within psychoanalysis which closely parallels the peculiar materialism

\footnotetext{
${ }^{45}$ Habermas, Knowledge and Human Interests, pp. $214 \mathrm{ff}$.

${ }^{46}$ The remainder of the present paragraph is adapted from a work previously published in the Religious Studies Review 4, 4, 248. In his most recent study of Freud, Ricoeur would seem to have confirmed this line of interpretation. See P. Ricoeur, "The Question of Proof in Freud's Psychoanalytic Writings," in C. Reagan and D. Stewart, eds., The Philosophy of Paul Ricoeur: An Anthology of His Work (Boston: Beacon Press, 1978).
} 
of the Frankfurt School; ${ }^{47}$ and with this final step we may have sufficient evidence for the pertinence of the transcendental background to an understanding of psychoanalysis. It must be stressed, however, that we have been dealing in parallels and analogies. Despite these approximations to the transcendental, there is a side of Freud's materialism which remains resolutely pre-Kantian. One may perhaps regret this, but regret is no warrant for allowing the flatfooted reality of what Freud actually said to evanesce into the hermeneutical subtleties of what one feels he should have meant. Freudian psychoanalysis finds its proper setting outside transcendental sphere-but in the most intimate proximity to it.

To the degree that we have now succeeded in showing that the transcendental background does illumine psychoanalysis, the illumination may be attributed to the fact that psychoanalysis had already been attempting, in effect, to replicate several of the philosophic options within itself, on the basis of its own premises. Earlier we saw that humanistic psychology tries in a similar fashion to fuse the transcendental and the scientific-empirical, and that existentialism is shaped by its effort to hold together the phenomenological and the critical. In effect each option seeks to incorporate the strengths of the other options, on the basis of its own premises. This suggests in turn that the sequence of options which we have traversed might best be conceived neither as a series of watertight compartments nor as an intermingling spectrum, but as a complex pattern of monads, each reflecting within itself a distinctive effort to grasp the entirety.

Much of this essay may be summarized by reference to the original diagram. At the center sits existential psychology, a microcosm of the larger philosophic tensions. Moving out a step in each direction, we might trace a circle which would describe the realm of transcendental discourse: the study has argued that phenomenology, existentialism and critical theory must be understood in terms of their common Kantian rootage; even their differences reflect a broadly Hegelian effort to preserve the essential Kantian insight, the transcendental turn. Yet another step and we encounter the positions which many earlier discussions had taught us to assume as antithetical. We can now appreciate the extent to which Freudian psychoanalysis and humanistic psychology in fact amount to mirror images of one another: the mixed method of humanistic psychology and the mixed discourse of Freudian psychoanalysis represent comparable efforts to fuse the Kantian discovery of subjectiv-

${ }^{47}$ The argument may be further extended by reference to a number of themes from critical theory. Martin Jay remarks, "the revisionists' vaunted sociological 'correction' of Freud really amounted to little more than the smoothing over of social contradictions. By removing the biological roots of psychoanalysis, they had transformed it into a kind of Geisteswissenschaft and a means of social hygiene. Their desexualization was part of a denial of the conflict between essence and appearance, of the chasm between true gratification and the pseudohappiness of contemporary civilization" (Jay, The Dialectical Imagination, p. 104). Cf. H. Marcuse, Eros and Civilization: A Philosophical Inquiry into Freud (Boston: Beacon Press, 1955); Jay, The Dialectical Imagination, pp. 106-12. 
ity with various understandings of the requirements of the natural sciences. Thus both might be located on the boundary of the transcendental realm; but if we allow the philosophers to define the transcendental turn as an all-or-nothing conversion, we must reckon that the positions lie outside that realm, though in the greatest proximity to it. A last step and we arrive at two positions which, because of their distinctively metaphysical character, are properly placed at the furthest remove from the transcendental core. Finally there is in addition to this horizontal movement a vertical tension between the clinical praxis of the humanistic, existential and Freudian therapies and the more disengaged theorizing of the phenomenologist and the critical theorist-a tension which is mediated but not resolved by the sharing of certain phenomenological and critical concerns.

Now typologies of this sort are useful in anticipating the strengths and liabilities of various alternatives. By the same token, however, the schematic viewpoint makes it difficult to come to even a provisional decision favoring one position over against another. Existentialism may seem the most central option, but then phenomenology may be more rigorous and critical theory more self-aware; humanistic psychology is perhaps more comprehensive but Freudian psychoanalysis may be more realistic ... each position has its virtues, but there is always another side as well. In this manner the possessor of the master schema may drift into a bemused contemplation which is faintly complacent, a posture which is self-forgetful in its very sophistication. To extricate ouselves from this lifeless equipoise, I think it imperative that we keep in touch with the thrust of our investigations. Time and again we observed that, in actual practice, what tends to get pushed aside is not just any random aspect of matters, but one particular facet-that which we may now call in a comprehensive way the "critical." Indeed a convenient way of making this crucial point is simply to recall the several uses which have been made of this protean term. First the term was employed in the manner of common usage; and it was noted, following Tillich and Niebuhr, that a certain critical edge is often lost in the course of revising Freud. Secondly the term was used in the stricter sense of Kant's "critical philosophy," and it was proposed that the transcendental discussion which Kant initiated may be the neglected element in many discussions of psychology. Thirdly the term was used to represent the Hegelian insistence upon the necessity of mediation, and it was argued that this is a requirement which even Kant himself did not fully appreciate. Finally the term was used in the manner of the Frankfurt School of Critical Theory, and we found reason to take seriously the contention that such analysis strikes upon entrenched resistances, resistances which are not only individual but institutional as well.

A similar muting of the critical aspect may be discerned in even so able a commentator as Paul Ricoeur. The achievement of Freud \& Philosophy lies not only in its close study of the Freudian texts, but also in its refusal to follow the lead of many earlier studies in simply adjusting psychoanalysis in the direction of phenomenology. What is bracing 
about Ricoeur is the robust affirmation that the distinctively critical aspect of psychoanalysis has positive value in its own right. Earlier I suggested that in its actual execution Ricoeur's work falls short of this intent. It is now possible to propose that the slippage may stem in part from his decision to view Freud under the rubric of a "hermeneutic of suspicion." The decision is consonant with Ricoeur's concern for philosophy of language, but I believe there are important respects in which the category "hermeneutic" proves insufficiently comprehensive, so that it skews the case which Ricoeur aims to make. For Ricoeur understands hermeneutics to be deeply allied with phenomenology; and one must wonder whether, by virtue of this alliance, the very notion of a "hermeneutic of suspicion" does not so tip the balance of discussion as to blunt from the outset the suspicion's critical edge.

For this reason I believe that the transcendental setting of the question is finally the more comprehensive: it better enables us to appreciate the origins and interactions of both the aspects, the phenomenological and the critical. When viewed strictly within the context of hermeneutics, the birth of radical suspicion tends to seem an anomaly, a mutation of modern culture suggesting something of the paranoid or the perverse. The transcendental background, in contrast, reveals the critical as arising out of the internal requirements of phenomenology, as an effort to safeguard the formative insight upon which phenomenology itself is grounded. This is by no means to detract from the very real value of hermeneutical discussion, over against the earlier, more flatly metaphysical point of view. But it is to suggest that the importance of the hermeneutical approach has become somewhat inflated of late, to the point of seeming all-encompassing. And at that point hermeneutics does need to be relativized by a recalling of its own philosophic origins. ${ }^{48}$

In closing I would submit that the slighting of the critical among humanists and theologians is so recurrent a phenomenon as to constitute a pattern, and that the recognition of this pattern of neglect lays an imperative upon those who would do theology in the present world context. In principle there is no dichotomy of subject and object, in principle we are parts of a larger whole. But in point of fact we live in a world which is rent by oppression and alienation. The theologian must exercise exceeding great care lest the affirmation which is meant to engender vision instead invite a certain blindness, a sort of proleptic

\footnotetext{
${ }^{48}$ Much of the power of Ricoeur's work may be attributed to his sensitivity to the transcendental context: witness the use of Hegel in Freud and Philosophy and the pervasive use of Kant. See D. Ihde, Hermeneutic Phenomenology: The Philosophy of Paul Ricoeur (Evanston: Northwestern University Press, 1972), pp. 59ff. Moreover Ricoeur's profound commitment to the discipline of the conceptual "detour" reflects a personal appropriation of the way of mediation; and conversely his abhorrence of premature cloture, the circle which reflection makes with itself, parallels the Frankfurt School's attack upon the philosophy of identity. But Ricoeur's detours are at the service of a certain notion of phenomenology, which indicates that the fundamental appeal is to a descriptive holism (cf. his frequent appeals to the "fullness" of symbolic language). Thus the critical moment does not attain to a significance in its own right and the consequent notion of the whole is, ironically, restrained. One can only conclude that holism is not enough.
} 
complacency. I am aware that my convictions in this regard have occasionally colored the exposition; particularly when I was striving to legitimate the critical over against the phenomenological, I may have been rather hard on humanistic psychology. I hope that the more balanced diagram which I have set forth may stand as an internal check against the occasional excess. But I do believe that something along this line is the proper use of such a schema-to try to hear the questions which it puts against one's own position while appropriating it, nevertheless, to hammer out the word which one judges most needs to be spoken in the fact of the present moment.

WALTER JAMES LOWE Emory University

Atlanta, Georgia 